\begin{tabular}{c} 
Volume and Issues Obtainable at Center for Sustainability Research and Consultancy \\
Journal of Accounting and Finance in Emerging Economies \\
ISSN: 2518-0318 ISSN (E) 2518-8488 \\
Volume 6: Issue 2 June 2020 \\
CSRC \\
Journal homepage: www.publishing.globalcsrc.org/jafee \\
\hline
\end{tabular}

\title{
Over-Indebtedness of Rural Micro-credit Financing in Bahawalpur: An Impediment to their Social \& Financial Mobility
}

\author{
${ }^{1}$ Owais Shafique, ${ }^{2}$ Maria Habib \\ ${ }^{1}$ Assistant Professor, School of Business, Management and Administrative Sciences, The Islamia University of \\ Bahawalpur, Pakistan, owais.shafique@iub.edu.pk \\ ${ }^{2}$ MS Scholar, School of Business, Management and Administrative Sciences, The Islamia University of Bahawalpur,
} Pakistan

\begin{tabular}{l}
\hline ARTICLE DETAILS \\
\hline History \\
Revised format: May 2020 \\
Available Online: June 2020 \\
\\
\hline Keywords \\
Micro-credit finance, poverty, \\
addiction, over-indebtedness, \\
women empowerment, social \\
and financial mobility \\
\hline
\end{tabular}

JEL Classification:

$M 0, M 1$

\begin{abstract}
The purpose of this study is to investigate the impact of micro-credit finance on over-indebtedness and social \& financial mobility of micro-credit finance participants. The objectives of this research is to investigate that micro-credit finance participation leads to over-indebtedness of micro-credit finance and over-indebtedness of micro-credit finance effect the social and financial mobility of micro-credit finance participants. The study also investigates the role of women participation in those financial decisions through which overindebtedness exist. The study is quantitative and the research design is explanatory in nature. The data was collected from 266 current and exmicro-credit finance participants through questionnaire and interview were also conducted in order to facilitate respondents. The data was analyzed through different statistical software I.e. Microsoft Excel and SPSS. The findings of the study indicate that micro-credit finance participants experience over-indebtedness by participation in micro-credit finance program but it does not affect the social and financial mobility of microcredit finance participants. It also evaluate that women involvement has weak mediating relation with over-indebtedness and financial mobility. This study has important implications because it provides insights regarding overindebtedness of micro-credit finance participants that effects their social \& financial mobility. This study also helps policy makers in formulating new regulations in the area of micro-credit finance sector in Pakistan. The new policies may target the aspect of over-indebtedness among micro-credit participants in future.
\end{abstract}

\section{OPEN ACCESS}

(C) 2020 The authors, under a Creative Commons Attribution-

NonCommercial 4.0

Corresponding author's email address: owais.shafique@iub.edu.pk

Recommended citation: Shafique, O., Habib, M. (2020). Over-Indebtedness of Rural Micro-credit Financing in Bahawalpur: An Impediment to their Social \& Financial Mobility. Journal of Accounting and Finance in Emerging Economies, 6(2), 559-569 


\section{Introduction}

Pakistan is the sixth most populated country of the world. According to the census of 2017, the population of Pakistan is about 197 million with $1.97 \%$ growth rate, where $29.5 \%$ of the population lives under the poverty line. Poverty is defined as living on less than $\$ 1.90$ a day according to the the World Bank. Poverty means the failure to fulfill basic needs due to the deficiency of financial and social services. Poverty is one of the chief issues facing Pakistan. Most of the people living under the poverty line rely on micro-credit finance to alleviate themselves out of poverty. A number of micro-credit finance institutions work in Pakistan and provide micro loans to poor people. These micro-credit finance institutions play an important role in the development of Pakistan. Micro-credit finance is viewed as a tool to alleviate poverty (Mia, 2017; Uri \& Leikem, 2012) and improving the living standard for its clients.

Hence, the focus of this study investigates over-indebtedness, and social and financial mobility of micro-credit finance participants (Mia, 2017). Micro-credit finance (MF) is a type of financial service that offers small loans to low-income or unemployed people. The aim of micro-credit finance is to provides loan to poor people to invest in their businesses and to eliminate poverty among those people (Adjei \& Arun, 2009). MF is used to improve the social and financial position of poor people especially females are included in this sector.

Micro-credit finance was first initiated by Dr. Muhammad Yunus in Bangladesh in 1970, and he was awarded the Nobel Peace Prize for his endless efforts against reducing poverty. Dr. Muhammad Yunus and Grameen Bank made efforts to uplift the poor of Bangladesh economically and socially by providing them small loans. This earned Dr. Yunus the title of "banker of the poor". Providing loans to poor people without any financial security seems to be a challenge, as micro-loans are perceived to be more riskier than commercial loans. However, he managed to turn his idea into practice by serving millions of people.

The Grameen bank gives a micro-credit loan between $\$ 27$ to $\$ 500$ to low-income people, to start or expand their small businesses. If the borrowers are able to repay their loans, they become eligible for larger loans. A slogan at Grameen bank is "If you give a man a fish you feed him for a day. If you teach him to fish, you feed him for a lifetime". The aim of micro-credit finance is to eliminate poverty, support self-employment and to empower poor people (Brana, 2012). Most of the loans are given to women, as they are contemplated as better at repaying loans than men Hence, about $94 \%$ of the loan are given to women.

The focus of this study is to determine the socio-economic impact of micro-credit finance industry in Pakistan. Most of the empirical studies on micro-credit finance indicates that, it works exceptionally well - like micro-credit finance reduces poverty, empowers women and improvs standard of living (Addae-korankye, 2012; Ahmed, 2014; Uri \& Leikem, 2012). But on the other hand academic literature demonstrate that micro-credit finance has some flaws, and the most important is over-indebtedness to MF (Gu, 2014a; Koomson, Peprah, \& Inclusion, 2018).

The study identifies that participation in MF leads to over-indebtedness. The study assesses the impact of overindebtedness of MF participants on their social and financial mobility. The study investigates the role of female participants in terms over-indebtedness of MF and social \& financial mobility.

\subsection{Research Questions}

i. Is micro-credit finance participation a source of over-indebtedness of micro-credit finance participants in Bahawalpur?

ii. Does over-indebtedness of micro-credit finance affects the social and financial mobility of micro-credit finance participants in Bahawalpur?

iii. Women participation mediates the relationship between over-indebtedness of micro-credit finance and social \& financial mobility of micro-credit finance participants in Bahawalpur? 


\subsection{Research Hypotheses}

H-I: Participation in micro-credit finance leads to over-indebtedness among micro-credit finance participants in Bahawalpur.

H-II: Over-indebtedness of micro-credit finance affects the social and financial mobility of micro-credit finance participants in Bahawalpur.

H-III: Women participation has a mediating relation between over-indebtedness and social \& financial mobility among the micro-credit finance participants in Bahawalpur.

\section{Literature Review}

Micro-credit finance is a type of financial service that offers small loans to low-income individuals who have no access to banks. The aim of micro-credit finance is to provide money to poor people to invest in their business and to eliminate poverty among those people (Adjei \& Arun, 2009). The micro-credit finance model was formed to eradicate poverty, Dr. Muhammad Yunus was the founder of this model and World Bank became the main supporter of microcredit finance model. Micro-credit finance is a response of worldwide economic problems such as high population growth, low economic development, poverty and lack of formal financial series to the poor (Drašarová \& Srnec, 2016).

Despite all those facts, it is not necessary that MF always provide relief, to the poor, sometimes it becomes a serious problem for its users. There are some negative aspects as well as positive aspects of MF. The negative aspect of MF is that, the clients of MF wants to stay longer with MF institutions and demand micro-credit finance throughout their life (Peprah \& Koomson, 2014) because they consider it an easy way to fulfill their needs. The client wants micro-credit finance over and over again to fulfill their needs and became addicted to micro-credit finance (Peprah \& Koomson, 2014).

The clients develops addiction through multiple borrowing of micro-credit finance from different micro-credit finance institutions at a time (Koomson et al., 2018). Multiple borrowing of micro-credit finance leads a client to overindebtedness. To avoid over-indebtedness, poor people borrowing multiple times but it is not a solution of their problems. Multiple borrowing, addiction to micro-credit finance and over-indebtedness are those major issues encountered by the poor micro-credit finance participants. Social mobility is the transformation of a person from one social class to other and financial mobility is the transformation of an individual from one financial structure to another (Peprah \& Koomson, 2014).

The factor of over-indebtedness is not only generated by the demand side factors of the clients of micro-credit finance programs but it is also generated by the supply side factors of the micro-credit finance institutions. After a thorough study of literature on over-indebtedness of micro-credit finance participants, it is evident that micro-credit finance is linked with numerous factors. These are the factors that lead participants of micro-credit finance program to overindebtedness. Some of these factors are positively linked with micro-credit finance and some are negatively linked. Let's discuss these factors in detail.

\subsection{Micro-Credit Finance as a Poverty Reduction Tool}

Micro-credit finance is generally acknowledged as provision of financial services to low income people to take advantage of those opportunities through start-up a new business or extending current business. Micro-credit finance has been used as a tool of poverty reduction (Samer, Majid, Rizal, \& Muhamad, 2015) as micro-credit finance increase job opportunities and lowers the unemployment rate and it is used as an effective tool for breaking the malicious circle of poverty all around the world (Drašarová \& Srnec, 2016). Participation in micro-credit finance programs has a signifiant impact on the social and financial condition of the poor participants.

Numerous studies argue that the success of micro-credit finance as a poverty reduction measure depends upon the indicators of micro-credit borrowers (Barai \& Adhikary, 2015), the reason is that micro-credit finance not only 
increases the income and consumption of the poor, but also impact the empowerment of poor. Micro-credit finance is considered as an important tool for the development of a country, a number of studies, from different countries, have attempted to gauge the social impact of MF in elevating poverty. A study conducted in Bangladesh, revealed that micro-credit finance plays a pivotal role in elevating poverty for any country (Mia, 2017).

Many researchers found that micro-credit finance has a positive impact on old clients of micro-credit finance as compared to new clients (Samer et al., 2015) due to multi-dimensions of poverty. The old clients of MF programs with low or no education becomes self-sufficient as compared to new clients. Another study by Uri and Leikem (2012), also investigated the impact of micro-credit finance as a tool for poverty eradication and determined that the poor people are the least likely to benefit from micro-credit finance due to the increase in provisions of micro-credit finance. In some cases micro-credit finance increases the poverty rather than reducing poverty due to the financial exclusion of micro-credit finance (Stewart, 2012).

\subsection{Micro-Credit Finance as a Source of Financial Inclusion}

In some cases micro-credit finance is considered that it is directly linked with financial exclusion (Preview \& Accounting, 2018). Financial exclusion is closely associated with poverty and social exclusion. It is a situation where financial services are inaccessible, such as no saving accounts, no insurance and no access to possible credit line. One of the key objectives of MF program is to provide financial services to those poor people, especially in the rural areas, who are excluded from such services offered by conventional financial institutions (Preview \& Accounting, 2018). The purpose is to provide micro-credit finance services to poor people who have no access to these services and lead to financial exclusion.

The financial exclusion restricts the ability of poor people to start a business and fulfill their needs. Several studies found that micro-credit finance program focuses on a disproportionate smaller number of poor people (Preview \& Accounting, 2018). As the poor people fail to keep up with installment repayments, the micro-credit finance institutes excludes these peoples and focuses on the remaining selective people. Another study that addresses the issue of access to financial services claims that the access to financial services is closely associated with the awareness of microcredit finance and its policies.

Financial inclusion refers to the provision of financial services to low-income people of developing countries at reasonable costs. It is estimated that about 2 billion people worldwide have no access to basic banking services. Therefore, financial inclusion is important for the development of developing countries, when poor people have access to financial services they have opportunities to improve their lives. In India a large number of studies were conducted to address the issue of financial inclusion, especially footing on credit which is a curtail component of economic development (Hans, 2018). The accessibility of credit in form of micro-credit finance at right time in right quantity contributes a lot in the welfare of a society.

\subsection{Micro-Credit Finance Linked with Over-Indebtedness}

Over-indebtedness can be defined as the inability of people to meet their repayments on any consumer credit that they have. It also refers to the permanent or temporary imbalance in family budget due to increase in spending and decrease in family income (Anderloni \& Vandone, 2008). There are three main causes of over-indebtedness, first one is when people wants to change their life, second cause is the over commitments made by people and the last cause is the competition to acquire a luxury life. In relation with poverty the examination of over-indebtedness shows that the results are very similar, it is clear that someone who is unable to repay his debt faces poverty.

Over-indebtedness lead to financial exclusion because cause-effect relation exist between over-indebtedness and financial exclusion (Gloukoviezoff, 2015). The expansion of banking sector performs a vital role in creation of household indebtedness (Roman \& Şargu, 2011), expansion of banking sector makes the credit easily accessible to the poor and cause over-indebtedness. Some studies argue that over-indebtedness is caused by financial inclusion, i.e. the ease with which any poor person can avail multiple micro-credit loans with little effort and accountability. These microcredit loan payments become a source of over-indebtedness among the poor. 
Several studies which set out to uncover whether easy availability of micro-credit finance leads to over indebtedness reveal that micro-credit finance cause over-indebtedness (Ali \& Alam, 2010). Micro-credit finance was developed with the sole purpose of poverty alleviation, however, it has tried into a nightmare that has the potential to cause more harm then good in the lives of the poor (Bastiaensen, Marchetti, \& Francisco, 2013). Studies suggest that micro-credit finance has lead a lot off poor people to commit suicide due to over-indebtedness (Gu, 2014b) .. Some studies claim that over-indebtedness is also the cause of multiple borrowing (Koomson et al., 2018).

\subsection{Micro-Credit Finance Linked with Addiction}

The term addiction refers to the inability off someone to stop consuming something. It is the use of something which takes the user to that point, where it becomes harmful for the user. At times the clients of MF become addicted to micro-credit financial services (Peprah \& Koomson, 2014) due to the over use of MF and multiple borrowing from MF programs/institutions. The clients of MF demand micro-loans over and over again to satisfy their basic needs, as they consider those micro-loans a cheap source of borrowing, this over use of MF cause addiction to MF.

The addiction of micro-credit finance is caused by multiple supply side and demand side factors (Peprah \& Koomson, 2014). The supply side factors include the unhealthy competition between micro-credit finance institutions and the demand side factors include the multiple borrowing of micro-credit finance. Both, supply side and demand side factors, cause addiction to micro-credit finance. The clients of micro-credit finance consider it a cheap source to satisfy their needs, they take micro-loans from different micro-credit finance institutes at the same time, because it is easily accessible from different micro-credit finance institutes at the same time and become addicts (Koomson et al., 2018).

The clients of micro-credit finance demand micro-loans frequently for their fundamental needs, such as for education purpose, for wedding purpose, for treatment, etc. These micro-loans are taken for non-productive purpose and are a major cause for over-indebtedness (Koomson et al., 2018). A thorough and comprehensive literature review on the literature in micro-credit finance revealed that micro-credit finance client needs financial knowledge to meet their desired outcomes. To avoid indebtedness of micro-credit finance loan repayment is necessary (Abdul \& Kamaluddin, 2015), for that purpose social collateral model has been developed which enlightens micro-credit finance clients on how to make repayments, and how to achieve social sustainability.

\subsection{Micro-Credit Finance Linked with Social and Financial Mobility}

Social mobility refers to the movement of a person or group of people in social positions such as moving from lowincome class to middle-income class over time. Moreover social mobility refers to the change in wealth and social status of a person or families. Like social mobility, financial mobility is the transition of an individual from one financial structure to other (Koomson et al., 2018). A study revealed that MF participation improves the social status of poor people to improve its brand image and the study father found that micro-credit finance participation has a potential and ability to create a channel to its clients to improve their social status (Ashta, Couchoro, Saleh, \& Musa, 2014).

Numerous studies have addressed the issue of mobility. In India, it was observed that micro-credit finance services are associated with mobility and the results show that not only micro-credit finance services but financialisation of development also creates mobility (Young, 2010). Another study from Pakistan which accessed the impact of MF on social mobility, concludes that there is a significant positive impact of micro-credit finance participation on social mobility (Muhammad \& Hamdani, 2012). The result comprise that micro-credit finance services improved the social mobility that eased poor people to raise their standard of living by providing financial opportunities.

Moreover, it is believed that micro-credit finance provides credit to poor people to improve their lives and improve their social status in society. Poor people use micro-credit finance to limb ot of poverty and move from the bottom of the pyramid to the paper ranks of lower class or from the lower class to the middle class (Peprah \& Koomson, 2014). Micro-credit finance is viewed as a key strategy to enhance the standard of living through empowering people and alleviate poverty by improving the social and financial status of poor people in the society. 


\subsection{Micro-Credit Finance Linked with Gender Biasness}

The term gender biasness is referred as the preferences toward one gender to another gender. Gender biasness exists when men and women are treated differently. In micro-credit finance gender biasness is considered as a factor that influences the policies of micro-credit finance. Numerous different studies conducted in different regions of the world on the impact of gender biasness on micro-credit finance revealed that gender biasness occurs in micro-credit finance $(\mathrm{Gu}, 2014 \mathrm{~b})$. The reason for this gender biasness is the empowerment of women. This fact is confirmed by the various studies from Bangladesh.

A study from Bangladesh set out to assess the women empowerment through micro-credit finance participation in rural areas and uncovered that micro-credit finance is very helpful for rural women to improve their position not only in family but also in the society through borrowing (Uddin, 2019). Women play a crucial role in the success of microcredit finance, that's why women become a focal point for poverty reduction. Uddin (2019) claims that in Bangladesh micro-credit finance works exceptionally well for women empowerment and women participation is about $88 \%$ as compared to men.

Despite these facts on women empowerment, women participation is absent in top leadership and women face discrimination. Empowering of women is associated with the economic development of women (Dutta, 2018). However, there is evidence that empowering of women is not actually the development of women due to many constraints that lead to the exclusion of women like illiteracy, lack of awareness, unfamiliarity with technology and many other factors. Literature also reveals that micro-credit finance causes over-indebtedness (Stewart, 2012), continently casing harm to the society instead of doing good.

This research has two basic variables as independent variable and dependent variable. The independent variable is the over-indebtedness of micro-credit finance participation (with sub-variables multiple borrowing, financial literacy, addiction to borrowing) and dependent variable is social \& financial mobility of micro-credit finance participants whereas the mediating variable is women participation. These variables are designed to evaluate the impact of overindebtedness of micro-credit finance participation on social and financial mobility of MF participants and also evaluate the role of women participation.

\section{Research Methodology}

This research study investigates the reasons of over-indebtedness of MF participants and its influence on social and financial status of MF participants and the role of women participants. This study is explanatory in nature and explains the negative effects of micro-credit finance participation in form of over-indebtedness of microcredit finance.

\subsection{Research Design}

The research examines the causal relationship between over-indebtedness of micro-credit finance and social and financial mobility of micro-credit finance participants. In this research the objective is to explain over-indebtedness of micro-credit finance as a weakness of micro-credit finance, there is very little data available on over-indebtedness of micro-credit finance, that warrants explanatory research on this topic. The research is quantitative in nature and data is collected through questionnaire. The same questionnaire was also used to interview the illiterate micro-credit finance participants.

\subsection{Statistical Population}

The focus of this study is on micro-credit finance participants of different MF institutes in Bahawalpur, Pakistan. Therefore, the population consists of the clients of micro-credit finance institutions. Cluster sampling technique was used to collect data. The data was collected from current and ex-participants of micro-credit finance. The data is collected through questionnaire survey methodology and interviews, the questionnaire adopts 5-point likert scale. The sample size is 266 which is an appropriate sample size for this study. 


\section{Data Analysis}

The data of the study at hand was collected through questionnaire and interview method. The data as analyzed in SPSS. The data was analyzed to assess the impact of over-indebtedness of MF participation on social and financial mobility of MF participants.

The data was further analyzed to access the role of female participation. For this purpose different test were run such as normality, multicollinearity, reliability, and KMO \& Bartlett's test, correlation, and regression. The data for this study is reliable based on the Cronbach's alpha of 0.824. The descriptive statistics are presented in Table 1.

\begin{tabular}{|l|l|l|l|}
\hline \multicolumn{4}{|c|}{ Table 1. Frequency Analysis of Demographic Information } \\
\hline & Frequencies & Percentage & Cumulative Percentage \\
\hline Gender & & & \\
\hline Male & 184 & 69.2 & 69.2 \\
\hline Female & 82 & 30.8 & 100.0 \\
\hline Total & 266 & 100.0 & \\
\hline Age & & & \\
\hline 20-30 & 101 & 38.0 & 38.0 \\
\hline 31-45 & 129 & 48.5 & 86.5 \\
\hline 46-60 & 36 & 13.5 & 100.0 \\
\hline Total & 266 & 100.0 & \\
\hline Education level & & & \\
\hline Secondary School & 21 & 7.9 & 7.9 \\
\hline College Level & 89 & 33.5 & 41.4 \\
\hline University Level & 156 & 58.6 & 100.0 \\
\hline Total & 266 & 100.0 & \\
\hline
\end{tabular}


Correlation Analysis

\begin{tabular}{|c|c|c|c|c|}
\hline \multicolumn{5}{|c|}{ Table 2: Correlations } \\
\hline & & Overindebtedness & AvgWI & AvgFM \\
\hline \multirow[t]{3}{*}{ overindebtedness } & Pearson Correlation & 1 & $.237^{* *}$ & -.031 \\
\hline & Sig. (2-tailed) & & .000 & .620 \\
\hline & $\mathbf{N}$ & 266 & 266 & 266 \\
\hline \multirow[t]{3}{*}{ AvgWI } & Pearson Correlation & $.237^{* *}$ & 1 & .096 \\
\hline & Sig. (2-tailed) & .000 & & .120 \\
\hline & $\mathbf{N}$ & 266 & 266 & 266 \\
\hline \multirow[t]{3}{*}{ AvgFM } & Pearson Correlation & -.031 & .096 & 1 \\
\hline & Sig. (2-tailed) & .620 & .120 & \\
\hline & $\mathbf{N}$ & 266 & 266 & 266 \\
\hline
\end{tabular}

Correlation analysis is used to assess the relationship between independent and dependent variables. The change in one variable brings change in other variable either positive or negative. The correlation analysis is used to find the strength of the relationship among variables and whether the direction of relationship is positive or negative. The range of correlation lies between +1 to -1 the signs show the direction of relationship among variables.

Table 2 shows the results for the correlation analysis, the results of Pearson Correlation Coefficient at $0.237,-0.031$ and 0.096 shows that independent variable is not significantly correlated with dependent variables. The results of Pearson Correlation Coefficient suggest that financial mobility is negatively linked with over-indebtedness at correlation value of 0.031 .

\subsection{Regression}

Regression analysis is used to examine the causal effect of one variable on another variable. It is used to analyze the influence of independent variable (over-indebtedness of micro-credit finance participation as MB, FL, AB) on dependent variables (financial and social mobility and women participation as mediator). The multiple regression analysis is used to test the relationship. The multiple regression analysis is used to analyze the hypotheses.

\begin{tabular}{|c|c|c|c|c|c|}
\hline \multicolumn{7}{|c|}{ Table 3: Results of regression analysis } \\
\hline Hypothesis & Df & M.S. & F & Sig. & Result \\
\hline $\mathbf{1}$ & 1 & 4445.911 & 186.090 & 0.000 & Significant \\
\hline $\mathbf{2}$ & 1 & .053 & .246 & 0.620 & Insignificant \\
\hline $\mathbf{3}$ WP $\rightarrow$ FM & 1 & .516 & 2.439 & 0.120 & Insignificant \\
\hline $\mathbf{3}$ OI+WP $\rightarrow$ FM & 2 & .343 & 1.619 & 0.200 & Insignificant \\
\hline
\end{tabular}

On the basis of results of regression analysis H-I is accepted which claims that micro-credit finance causes overindebtedness among its clients. The H-II is rejected on the basis of the results, which claims that over-indebtedness of micro-credit finance has not affect on the social and financial mobility of micro-credit finance participants. 
Table 3 shows the regression results of direct link of women micro-credit finance participation and financial mobility, and the results conclude that women participation has a no significant relationship with social and financial mobility with $\beta=0.096$ and $p$ value is more than 0.05 . The result evaluate that women participation has no influence on social and financial mobility.

Table 3 further shows the overall link of over-indebtedness of micro-credit finance and women micro-credit finance participation on social and financial mobility. The results indicate that both the variables have no significant relationship on financial mobility of micro-credit finance with $\beta$ values $=-0.056$ and 0.109 and $p$ values are more than 0.05 .

The findings of the above analysis evaluate that over-indebtedness of micro-credit finance has negative relation with financial mobility and women participation has positive but weak relationship with financial mobility. On the basis of these findings we conclude that women participation acts as a weak mediator in the relationship between overindebtedness of micro-credit finance and social \& financial mobility.

Hence, H-III is also rejected, and concludes that women participation acts as a weak mediator in the relationship between over-indebtedness of micro-credit finance and social \& financial mobility.

\section{Conclusion}

This research was conducted in Bahawalpur, to investigate that whether over-indebtedness of microcredit finance affects the social and financial mobility of micro-credit finance participants in Bahawalpur. Furthermore, this research examine the mediation impact of women participants on the relationship between over-indebtedness and social \& financial mobility.

The results and findings of the research conclude that one hypothesis of the research is rejected and accept the other two hypotheses. The overall result of the research concludes that micro-credit creates over-indebtedness but overindebtedness does not affect the financial mobility of its clients. It also concludes that women participation has a mediating impact on over-indebtedness and financial mobility. These finding confirm the two of three hypotheses.

\section{Potential for Further Research}

The results of the research give us a serious consideration about micro-credit loans for micro-credit finance institutions. Prior to what we initially theorized, the results turned out to be the complete opposite.

i. Any future study should focus on the current and ex-participants of micro-credit finance in other areas of Pakistan.

ii. The future study should use a larger sample size.

\section{Implications}

The scope of this research study is very vast. The study is significant as it determines the flaws of micro-credit finance. The micro-credit finance industry is growing rapidly and causes harm for its clients in term of addiction and over-indebtedness. The poor people are easily trapped in the debt trap and indulge in heavy loans, as it seems a cheap source of financing but actually it is not.

It's a cause of concern for society and necessary actions should be taken to avoid those issues in future. This research study is helpful for policy makers to make regulations in micro-credit finance sector to achieve the desired outcomes from this industry. 


\section{Limitations}

The limitations of this study are as follows:

i. The first and most obvious issue of this research is the biasness of responses. The data was collected through questionnaire and biasness on the part of the respondents is prevalent.

ii. The second limitation is sample size, the sample size is imperatively small.

iii. The third constraint is of time. Due to specific time the research is limited to Bahawalpur and the limited clients of limited micro-credit finance banks in Bahawalpur.

\section{References}

Abdul, N., \& Kamaluddin, A. (2015). Social collateral, repayment rates , and the creation of capital among the clients of microfinance. Procedia Economics and Finance, 31(15), 823-828. https://doi.org/10.1016/S2212$5671(15) 01172-7$

Addae-korankye, A. (2012). Microfinance : a tool for poverty reduction in developing countries, 7(1), $138-149$.

Adjei, J. K., \& Arun, T. (2009). Poverty Reduction: The Case of Sinapi Aba Trust of Ghana March 2009 BWPI Working Paper 87, (March), 1-23.

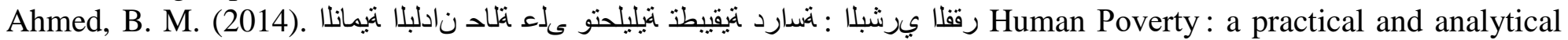
study on Less Developed. AEBJ, 9(1), 1-11. https://doi.org/10.1016/j.aebj.2012.05.001

Ali, A., \& Alam, M. A. (2010). Role and Performance of Microcredit in Pakistan.

Anderloni, L., \& Vandone, D. (2008). Households over-indebtedness in the economic literature, (January).

Ashta, A., Couchoro, M., Saleh, A., \& Musa, M. (2014). Dialectic evolution through the social innovation process : from microcredit to microfinance, 1-24.

Barai, M. K., \& Adhikary, B. (2015). The Success of Microcredit in Bangladesh : Supplementing 'Group Lending ' Explanation with Institutional Understanding, (June 2013).

Bastiaensen, J., Marchetti, P., \& Francisco, P. (2013). After the Nicaraguan Non-Payment Crisis : Alternatives to Microfinance Narcissism, 44(4), 861-885. https://doi.org/10.1111/dech.12046

Brana, S. (2012). Microcredit: an answer to the gender problem in funding? To cite this version: HAL Id: hal00740098.

Drašarová, M., Srnec, K. (2016). Microfinance as a Tool for Poverty Reduction: A Study in Mexico, Mediterranean Journal of Social Sciences, (September). https://doi.org/10.5901/mjss.2016.v7n5p18

Dutta, T. (2018). Economic Development and Women: Role Played by Financial Inclusion, (October). https://doi.org/10.2139/ssrn.3102809

Gloukoviezoff, G. (2015). The link between financial exclusion and over-indebtedness, (August).

$\mathrm{Gu}$, I. (2014a). The social meaning of over- indebtedness and creditworthiness in the context of poor rural South India households ( Tamil Nadu ) Isabelle Guérin Marc Roesch Venkatasubramanian Santosh Kumar, (November).

Gu, I. (2014b). Working Paper Gender bias in microfinance Bert d 'Espallier Isabelle Guérin, (June).

Hans, V. B. (2018). Financial Inclusion and Micro-Finance in India: An Overview Financial Inclusion and Microfinance in India : An Overview, (February 2008). https://doi.org/10.2139/ssrn.1089680

Koomson, I., Peprah, J. A., \& Inclusion, F. (2018). Multiple Borrowing, Over-Indebtedness, and the Microcredit Addiction Syndrome: Evidence from Some African Countries, (January). https://doi.org/10.2139/ssrn.3238646

Mia, A. (2017). An Overview of the Microfinance Sector in Bangladesh An Overview of the Microfinance Sector in Bangladesh, 7(May). https://doi.org/10.13106/eajbm.2017.vol7.no2.31

Muhammad, S., \& Hamdani, Q. (2012). I NTERDISCIPLINARY J OURNAL O F C ONTEMPORARY R ESEARCH I N B USINESS THE IMPACT OF MICROFINANCE ON SOCIAL MOBILITY , AN EMPIRICAL EVIDENCE FROM PAKISTAN, 81-89.

Peprah, J. A., \& Koomson, I. (2014). Addiction to Microcredit: An Obstacle to Social And Financial Mobility, (March 2018). https://doi.org/10.2139/ssrn.2976094

Preview, P., \& Accounting, S. (2018). Microfinance Programmes and the Poor: Whom Are They Reaching? Evidence from Ghana Whom Are They Reaching ? Evidence from Ghana Joseph Kimos Adjei 1 and Thankom Arun 2 University of Central Lancashire BWPI Working Paper 72, (May 2014).

Roman, A., \& Şargu, A. C. (2011). EU NEW MEMBER STATES HOUSEHOLDS 'BANKING INDEBTEDNESS AND IT 'S IMPLICATIONS : AN OVERVIEW, 13(2), 461-476. 
Samer, S., Majid, I., Rizal, S., \& Muhamad, M. R. (2015). The Impact of Microfinance on Poverty Reduction: Empirical Evidence from Malaysian Perspective. Procedia - Social and Behavioral Sciences, 195, 721-728. https://doi.org/10.1016/j.sbspro.2015.06.343

Stewart, R. (2012). The Impact of Microfinance in Sub-Saharan Africa: A Systematic Review of the Evidence. World Development, 40(11), 2249-2262. https://doi.org/10.1016/j.worlddev.2012.03.012

Uddin, S. S. (2019). Microcredit Towards Achieving Women Empowerment : From the Perspective of Rural Areas of Bangladesh MICROCREDIT TOWARDS ACHIEVING WOMEN EMPOWERMENT: FROM THE PERSPECTIVE OF RURAL AREAS OF, 49(5), 79-86.

Uri, D., \& Leikem, K. (2012). Microfinance: A Tool for Poverty Reduction? Microfinance: A Tool for Poverty Reduction? Senior Honors Project. 